\title{
Distrust of the Legal Establishment in Perspective: \\ Maryland During the Early National Years
}

\author{
BY JEFFREY K. SAWYER*
}

$\mathrm{D}$

espising lawyers has been popular for centuries, and knowing when to take it seriously is often difficult. ${ }^{1}$ Since the 1640s in England, vicious attacks on lawyers and the common law have occasionally accompanied reform movements. Are these outbursts evidence of a long-term tradition of radical hostility towards the legal establishment? Or do they point to a tradition of political posturing with little real substance?

With respect to early America, some very good historians have come to differing conclusions on these questions. Maxwell Bloomfield suggests that, while radical in tone, the attack on lawyers was rooted in essentially middle-class values and was not seriously connected to an ideology of social leveling or egalitarianism. ${ }^{2}$ He nevertheless demonstrates elegantly that the anti-lawyer sentiment of the Jacksonian period was part of a longer-term and culturally pervasive pattern. Richard Ellis's work, in partial contrast, documents radical attacks on the legal establishment during the Jeffersonian years, notably in Kentucky, Massachusetts, and Pennsylvania. ${ }^{3}$ Other legal historians have often stressed that fundamentally different conceptions of law, lawyers, judges, juries, and courts shaped the legal politics of Americans in the post-revolutionary years. ${ }^{4}$

Developments in Maryland offer an excellent opportunity to explore such issues further. From 1790 to 1810 a reform movement in the state led to important changes in the legal system. The legislature codified testamentary law and

* Director of Legal and Ethical Studies, Department of History and Philosophy, University of Baltimore 
parts of the criminal law, modernized the penal laws, gave more power to the local county courts, and made trial by jury more practical. ${ }^{5}$ Certain procedural reforms even aimed at eliminating lawyers' abuses. ${ }^{6}$ Some reformers promoted these changes in stridently anti-lawyer language, but most of the reforms were moderate.

A radical wing of the movement, however, specifically designed proposals to eliminate lawyers from the conduct of legal business. Such proposals included a small debt law and a system of arbitration. ${ }^{7}$ In its extreme form, the small debt bill might have taken most debt litigation out of the courts altogether and placed it in the hands of justices of the peace. The system of arbitration, which was designed to substitute for any civil litigation, also aimed at dramatically reducing the number of trials in court.

A genuine law reform movement brought about these legal changes. ${ }^{8}$ Republican ideology and party alignments, backed by demographic shifts that created pressures for change, also played an important role. ${ }^{9}$ Moderate, reformminded lawyers often took the lead, and in the end, controlled the overall direction of legal change. But popular distrust of the legal establishment, connected to a radical ideology of localism and democratic egalitarianism, provided a crucial base of support. Historians have linked this attack on lawyers and the judiciary to a broad cultural shift in attitudes towards authority. ${ }^{10}$ But the anti-lawyer movement also had a logic of its own.

This analysis of Maryland's post-revolutionary law reform movement begins with a closer examination of anti-lawyer sentiment and propaganda. It then explores the politics and logic of legal reform and concludes with some broader considerations of the significance of the Maryland story. Four kinds of primary sources-1) the votes and proceedings of the legislature; 2) the resulting statutes; 3 ) the related campaign in the press, and 4) the observations of politicians and lawyers personally involved-provide the evidence. These sources reveal a complex and interdependent range of antilawyer attitudes, political commitments, and demands for legal change. Hostility towards lawyers and demands for law 
reform were based in part on local conditions in Maryland, but also interacted with the politics of neighboring states, a national political struggle, and long-term traditions of antilawyer politics in western culture.

\section{Anti-Lawyer Radicalism}

Maryland reformers used radical arguments against lawyers and the common law that sometimes resembled the language of the radical law reformers of mid-seventeenth century England." A number of reformers in Maryland shared the main concerns of William Sheppard, for example, who, in his capacity as an adviser to Oliver Cromwell, advocated a decentralized and less formalistic common law. ${ }^{12}$ Like their English precursors, however, the Maryland law reformers were in fact a heterogeneous group. ${ }^{13}$ Maryland provides little evidence of a seventeenth century style legal fundamentalism, which sought to link legal reform to an Old Testament vision of law. ${ }^{14}$ Yet a similar distrust of the legal establishment and yearning for simpler justice pervaded the movement.

Distinguishing the radical perspective from that of the moderate, more professionally-minded reformers is useful. Whereas moderate reformers emphasized the need for efficient, reliable procedures, radicals often advocated dramatically different procedures and even justice without lawyers. Like their counterparts in France, Maryland radicals wanted the impetus of revolution to carry over into law reform; they wanted to break the monopoly of lawyers, simplify legal procedures, and promote "conciliation and arbitration in place of formal litigation." 15 Some Maryland radicals portrayed lawyers as using the medieval rituals of an old-world guild to further their own interests, reinforce a hierarchical social structure, and promote undemocratic modes of government. Such censure occasionally included attacks on the whole common law tradition. From this perspective, law was supposed to be laid down in black and white by the legislature and available for all to see and use. Any more complex idea of law would not involve recourse to a learned 
tradition but to a common sense understanding of justice, that is, to the natural capacity of ordinary people to know right from wrong. Radicals saw the lawyers' pretensions to learning as mostly a ruse. They publicly alleged that lawyers manipulated doctrinal ambiguity for self-serving reasons. ${ }^{16}$ They claimed further that lawyers promoted an artificial language of law designed to guarantee the need for professional interpreters and defeat the purpose of statutes. The legal elite, they charged, monopolized powerful, centralized institutions of government that usurped the discretionary powers of both the elected legislature and local magistrates. Judges presided over an intricate system of procedural rules designed more to cause delay and generate fees than to serve the interests of justice.

Newspaper articles used by reformers to mobilize popular support often reflected these radical views. At a key point in the struggle for court reform, a Baltimore newspaper championed the principle that sometimes law should be disengaged from formal learning and legal training. The author defended a new bill reorganizing the judiciary and noted that it preserved on the bench of every county court a seat for one layman, who would use his common sense to put a stop to lawyers' chicanery.

The great mass of the people have found business to proceed much faster by mixing a little common sense with legal knowledge.... I know many private gentlemen, who possess more accurate legal erudition than the majority of attorneys, although, perhaps, not so well acquainted with trick and finesse. ${ }^{17}$

For obvious reasons, a lay judge would be much less likely to indulge the bad habits of lawyers, the author alleged:

A judge who has practiced at the bar, will generally feel partial to the fratemity, and on most occasions wink at their sins of omission and commission; whilst the wearied and harassed suitors pay for it, both with purse and patience. ${ }^{18}$

This hostility towards the "fraternity" and impatience with the tactical use of procedural law constituted important dimensions of the radical position.

Local conditions clearly contributed to the development 


\begin{abstract}
To the Executive of the State of Maryland.
I AM aware of the objections that may be advanced against you, should rou pursue a mode of conduct like that witich I pointed out in my last. The gentlemen of the bar will press upon you, and insise. that the expression "legal talents" implits a frofestional education to the law. But you, who sufficiently understand language to judge of such matters, are not to be bound by explanations founded. in interested inotives ; nor will you be compelled to square your conduct in making appointunents to judgeships so as exactly to meet the wishes of lawyers alone. It is said that the present anamalous system observed in the county courts is complained of as a grievance : But by : whoin is the complaint made? Not by the body of the feofle, I assure you. The fuint murmurs that have eeked out, I venture to say it, have been made by lawyers, or men under the infuience of that profession. They have conceived themselves dishonored by having plain, honest men put along with them on the judgment seat : But the great mass of the people have found business to proceed much faster by mixing a little common senic with legal knotuledge. The presene associates have been more ready and willing to discharge their duties than you will find one lawyer judge in an hundred. Yet mistake me not; my representations do not go to the extent that some mny imagine. I do not desire that you should appoint men to office whether they be acquainted with the laws of the land or: not: On the other hand you should always ascortain, previous to an appoint-: ment, whether the person you fix upon for a judge has a sufficient knowledge of the laws of the state: But, then, you should make the enquiry general, and not fresume in one case and dowt in another. You should not take it for granted that. because a man has been bied a lawyen. he nust, of course, understand law; ami
\end{abstract}

The second article in an anonymous series champions the restructuring of Maryland's judiciary and criticizes the legal "fraternity." Baltimore American, November 29, 1805. (Courtesy Maryland Historical Society, Baltimore) 
of such attitudes. As in the other mid-Atlantic states, many of the leading lawyers and judges of post-revolutionary Maryland were highly trained. ${ }^{19}$ With their superior knowledge of legal procedures, concepts, and history, they were skillful at manipulating the state government. Worse still, lawyers had clearly profited from the legal confusion and financial crises in the decades following independence. ${ }^{20}$ This situation fueled resentment and encouraged the view, even among some establishment politicians, that lawyers were the vestiges of an Anglo-American aristocracy. Local perception was linked to national issues, in part through the behavior of Federalist partisans, such as Samuel Chase of Maryland. ${ }^{21}$ For anti-lawyer Marylanders, the pattern of Federalist policy looked sinister: the legal aristocracy supported the Adams administration, and the administration in turn supported the interests of lawyers and judges through such subterfuges as expanded federal courts and the Alien and Sedition Acts. ${ }^{22}$

Such anti-lawyer sentiment combined with the interests of the pragmatic reformers to push dozens of initiatives for major legal change through the legislature over the course of two decades. But like other reformers, the Maryland radicals also ran into a pattern of obstacles: vested economic interests, the public fear of radical change, the basic social need for technical expertise in the law, the desire of men in power to maintain control of the state, legislative battles and their myriad entanglements, lack of a coherent vision on the part of their own radical forces, and perhaps especially the conservatism of the legal profession even among lawyers who were political allies. ${ }^{23}$

\section{Law Reform and the Jeffersonian "Coup"}

During the mid-1790s dissatisfaction with various elements of the legal system was highly evident in Maryland, but members of the House of Delegates in the General Assembly generally took independent stands on legal issues. ${ }^{24}$ After 1795, as the contest between Federalists and Republicans developed into a full-scale party system, partisan rhetoric and block voting in the state legislature became more 
prevalent on both sides. Politicians on one side tried to tap the reservoir of popular resentment against lawyers. Those on the other side, opponents of reform, tried to tap into popular fear of a weak, overly partisan, or unreliable legal establishment. When campaigns in the press began to reflect these efforts, the links between democratic egalitarianism, legal reform, and political strategy became more pronounced.

In Maryland, as in Pennsylvania and other states, the flurry of anti-lawyer rhetoric and initiatives for legal change revolved to a considerable extent around political attacks on the judiciary. ${ }^{25}$ Contemporaries and historians have interpreted the onslaught as an episode in the emerging party system, which pitted the older faction, dominant since the federal government was established in 1789, against rival Jeffersonian Republicans. Federalist lawyers and judges, notably the ubiquitous Chase, encouraged this partisan interpretation. Chase railed from the bench against opposing

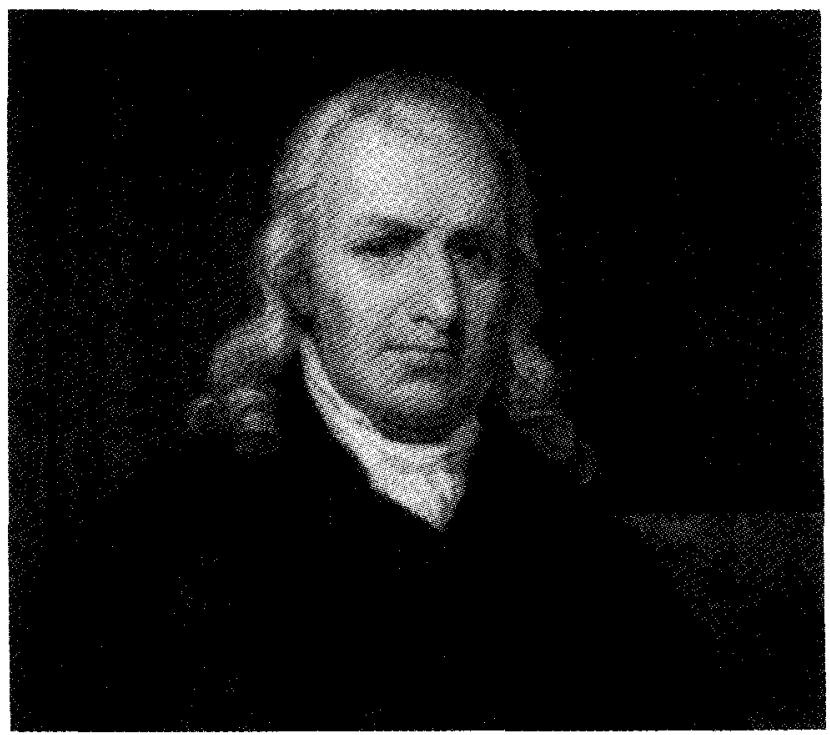

Samuel Chase, a volatile Federalist statesman and judge, served on the Maryland General Court from 1791 to 1796 and the U.S. Supreme Court from 1796 to 1811. The Senate impeached him in 1804, but he was acquitted in 1805. (Courtesy Maryland Historical Society, Baltimore) 
legal philosophies and portrayed opposition to Adams's administration and resistance to judicial power as undermining the foundations of the country's legal system. ${ }^{26}$ Other Federalists also trumpeted the dangers of egalitarian leveling and pointed to the alleged lessons to be learned from France's revolutionary misfortunes. One staunch conservative from Maryland complained in a letter to Alexander Hamilton that "anarchy" was likely to result from this "spirit of Jacobinism, under the worn out guise of equal liberty and right." 27

The opposite view, however, proved enormously powerful. This was the notion, promoted by Thomas Jefferson as early as 1784 , that the revolutionary heritage needed to be reclaimed because the sovereign people remained half-shackled by a regime of privilege and hierarchy protected by law. ${ }^{28}$ Maryland Democrats shared this view. Dr. John Archer wrote

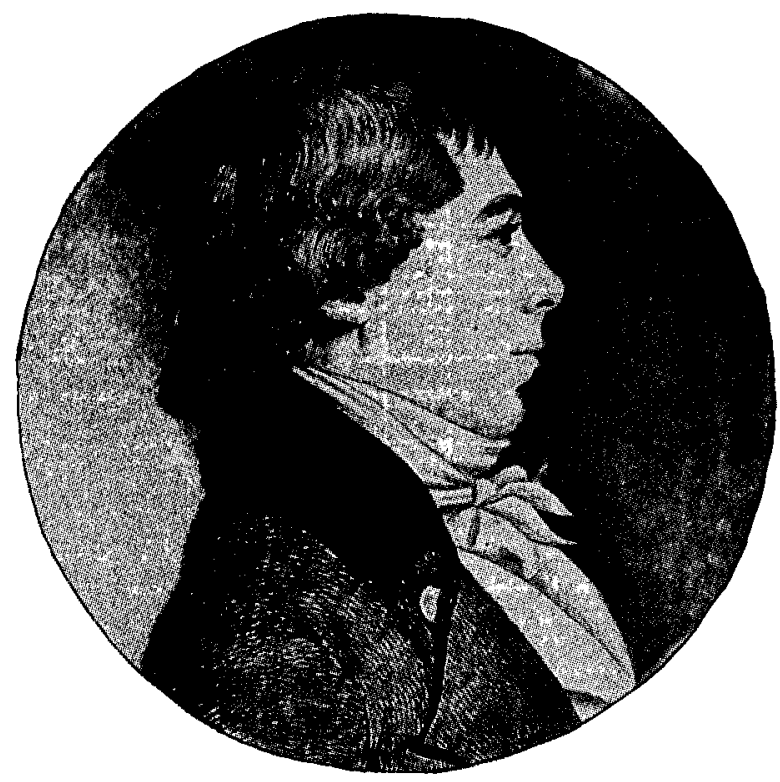

Dr. John Archer (1741-1810) received the first degree in medicine offered by an American school, an M.A. from the Philadelphia College of Medicine. A Democrat, he served as a Harford County delegate to Maryland's constitutional convention of 1776 and as a U.S. congressman from 1801 to 1807. (Courtesy Maryland Historical Society, Baltimore) 
to his son in September 1799 to explain that while the French revolutionaries had carried things too far for the cause of republicanism, aristocracy and monarchy were forms of evil that still stalked the earth and must be everywhere destroyed. ${ }^{29}$ Elected to Congress as a Democrat, Archer's letters from Washington praised Jefferson's unaffected style and defended the Republican assault on the federal judiciary. ${ }^{30}$

With the help of Democrats such as Archer in outlying counties, the Jeffersonian Republicans took control of the Maryland government in the elections of 1800, 1801, and 1802. Campaigning often focused on the "aristocratic" tendencies of government officials and undemocratic suffrage laws. Republican electioneering emphasized the national context of opposition to Adams's administration, foreign policy issues, and support for Jefferson's party. ${ }^{31}$ Democrats, who often distinguished themselves from Republicans, placed more emphasis on state and regional issues and the need for election reforms. Over the next decade the DemocraticRepublican coalition instituted radical changes in Maryland, including the democratization of voting and office-holding requirements for all white, male residents. ${ }^{32}$ The coalition also supported legal reform.

Such political forces were in some measure a product of demographic changes in Maryland that linked social reality to political ideology, state politics, and national political trends. Baltimore's population was growing dramatically, much more rapidly than that of the state as a whole, and the city was quickly becoming the political center of gravity for the state. ${ }^{33}$ Men who were excluded from voting in state elections by the property and residence qualifications and who were also non-English or members of religious minorities comprised a significant portion of the growing population. Moreover, among those who could vote, there must have been many who were angered and humiliated by the ritual of proving their net worth in order to vote or by their exclusion from officeholding by even higher property qualifications. ${ }^{34}$ In 1800, 1801, and 1802 the Democratic-Republican coalition made inclusive politics and electoral reform 
central to their victorious election campaigns. ${ }^{35}$ Popular political support and links to ethnic and religious minorities helped a new elite of merchants come to dominate the city of Baltimore, the surrounding county, and other central Chesapeake counties on both the western and eastern shores. ${ }^{36}$

Court reform and the democratization of the electoral laws thus formed the core of a broad political agenda. Both measures promised a state government more responsive to the needs of "the people." And while court reform began in earnest as early as 1790 , the major overhaul came in the six years following the Republican coup of 1800. Doctrinal and procedural reforms were of great importance, but the central battle concerned localizing judicial power in the county courts. Immediately upon their assumption of power in 1800 , the Democratic-Republican coalition made it clear it would reorganize Maryland's judicial establishment along new lines.

A letter from William Pinkney to his brother Ninian illustrates the effect of this prospect on conservatives. ${ }^{37} \mathrm{Wil}$ liam tried to calm his brother, who had apparently written to him in something of a panic after the tumultuous legislative session of 1800 was followed by a campaign in 1801 in which the Jeffersonians threatened to win again. William responded, "I hope you are deceived as to the possible consequences of the ensuing State Elections-What has Thos. Jefferson's being President of the U.S. to do with your General Court-Chancery etc.?" 38

William Pinkney was sufficiently concerned himself, however, to review the arguments against the judicial system and suggest a strategy for derailing the Republicans' plans. His analysis indicates that, while he personally disapproved of the reforms, he believed some of the reformers were motivated by practical or principled considerations. Court reform was more than a matter of "the ascendancy of this or that political party in the Nation at large." ${ }^{39} \mathrm{He}$ reminded his brother that such attempts had been made before and gave several specific reasons why people might support a reorganization of the courts. 


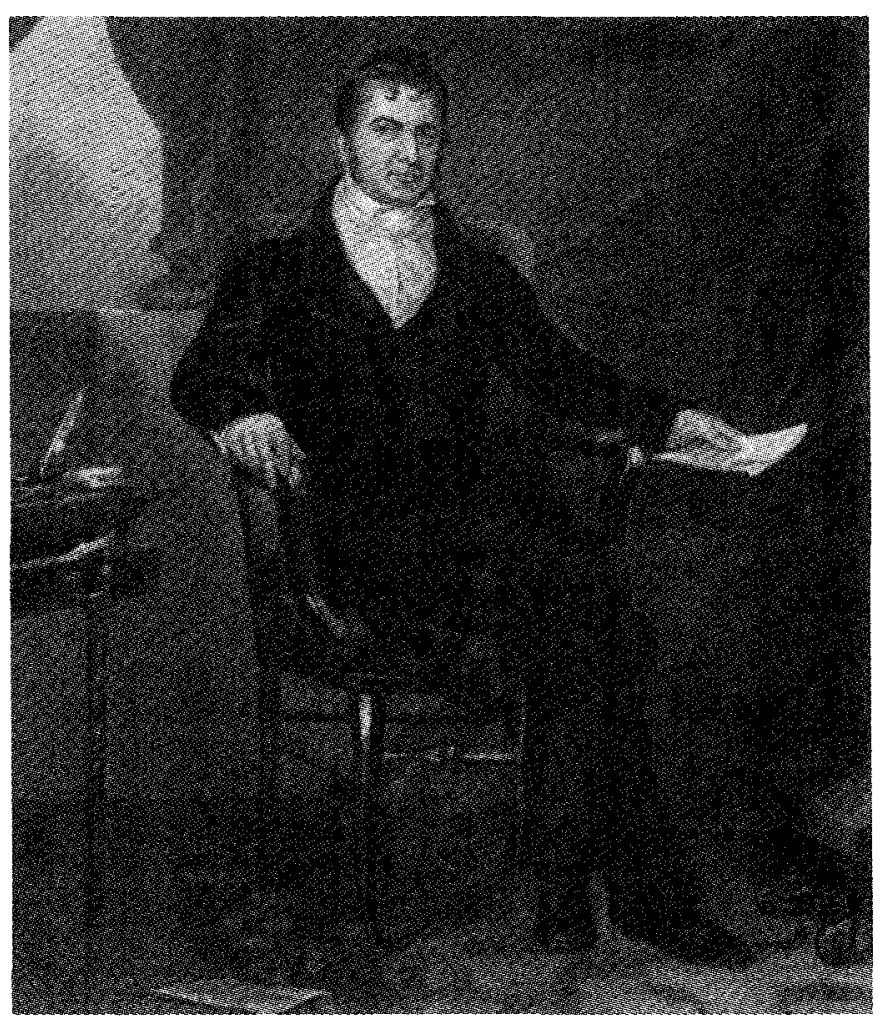

William Pinkney (1764-1822), a distinguished lawyer and statesman, served from 1796 to 1804 as an agent in England for both Maryland and the United States. He served from 1805 to 1806 as attorney general of Maryland. (Courtesy Maryland Historical Society, Baltimore)

The Peril, in which these Establishments manifestly are... [also] may be found [1] in the local Interests of the different Counties at any Distance from the Seat of Justice; [2] in the Interests of the attorneys who swarm in every part of the State and in the House of Delegates; [3] in the plausible and popular nature of the Theory that Justice should be brought home to Men's Doors and [4] that it should be cheap, easy, and expeditious; [5] in the Love of Change which half of the world believe to be synonymous with Improvement; [6] in the Disgust of Parties who have lost their Causes and their money at Annapolis or Easton, and [7] who imagine they would have done better in the County Court; and [8] a thousand other Causes that a long speech only could enumerate. ${ }^{40}$

By using language that emphasized public ignorance and 
discontent, Pinkney played down the issues of principle. But his strategy for defeating the change clearly recognized its roots in both Democratic and anti-lawyer opinion. Particularly notable are his references to the need for cheap, accessible, local justice and to the "swarm" of lawyers in the legislature, remarks which suggest some sympathy with the reformers.

Pinkney's emphasis on the importance of localism was also prescient. As the legal reforms of the 1800-1810 period unfolded, the voting blocks in the General Assembly were markedly regional as well as partisan.

\section{The Judiciary Bill of 1801}

In 1801, on the heals of a Republican victory in both houses of the General Assembly, a bill popularly referred to as the judiciary bill became law. ${ }^{41}$ It was a victory for the Republicans and those who wanted to decentralize the administration of justice. Maryland's judicial establishment had preserved virtually intact the pre-revolutionary arrangement of trial courts. ${ }^{42}$ Most major cases were heard in the state's General Court or in Chancery, where highly trained lawyers and judges dominated the proceedings. Only slightly reorganized from pre-revolutionary times to comprise an eastern and western division, the General Court remained the functional equivalent of the old Provincial Court. ${ }^{43}$ And while the jurisdiction of the county courts was expanding, the General Court remained the hub for major civil litigation and appeals. ${ }^{44}$ The Court of Appeals, shadowing the old governor's council, stood at the apex of the system. ${ }^{45}$ Though superior in theory, the highest court was a relatively minor force in practice, due in significant measure to the greater volume of cases in the General Court and to the eminence and professionalism of its justices. ${ }^{46}$ Samuel Chase and his cousin Jeremiah Townley Chase, Robert Goldsborough, and Gabriel DuVall all served at some point in their careers on the General Court bench. This arrangement not only looked like the system of colonial days, it concentrated enormous power in the hands of the General Court's three justices. 
This high degree of centralization, with its accompanying procedural formality and continued reliance on English authorities, combined with other holdovers from late colonial times, such as the unwieldy system of testamentary law, led to increasing demands for reform in the mid-1790s. Centralization was a particular problem with respect to jury trials. Trials would often take place not in the counties where the plaintiffs, defendants, witnesses, and jurymen lived, but in Annapolis or Easton-a burdensome and expensive journey for many. ${ }^{47}$ Eliminating this problem formed the nucleus of an extended campaign to reform the judiciary, in which many lawyers participated.

Developments out of state also contributed to the desire for change in Maryland. The adoption of the federal Constitution in 1789 aroused considerable public debate about the proper role of courts in a republican political system and the proper separation of powers. ${ }^{48}$ The Judiciary Act of 1789 , with its system of districts and circuits, provided a possible model for modifications at the state level, and subsequently in Pennsylvania the wisdom of having strong district courts at the county level was hotly debated at the constitutional convention of 1789-1790.49 Between 1790 and 1805, Virginians fought a lengthy and highly politicized battle over district courts, a reform in which local versus centralized judicial power was the key issue. ${ }^{50}$ These public debates focused attention on the fact that courts were political institutions and that they could and should be reorganized in a way that would best serve the needs of the public. ${ }^{51}$ The organizational issue of central versus local trial courts was intensified through its association with related controversies-traditional, highly formal versus "common sense" procedures; professional versus lay judges; and a politically responsive versus an independent judiciary.

This last issue caught fire simultaneously in Maryland and at the federal level. Partly because of their own state's similar experience with judiciary bills, as explained below, Maryland's representatives became deeply embroiled in the debate at the Capitol about whether or not to repeal Adams's Judiciary Act of $1801 .^{52}$ Both sides had ample ba- 
sis for their accusations of partisanship. Maryland's judiciary bill of 1801 also empowered the party in control of the governor's office and council to remove judges who were political opponents. Abraham Shriver of Frederick County believed at first that the result would be "an entire new bench," along with "a very extensive Sweep... of the Federal[ist] Magistrates" as a whole. ${ }^{53}$

Prior to 1800 , court reform in Maryland had often focused on problems of professionalization. The 1790 "Act for the better administration of justice in the several counties of this state" and its 1796 reenactment reveal this concern. ${ }^{54}$ These laws established a system of judicial districts within the state and provided for the appointment of chief justices "of sound legal knowledge" for each of the five districts to preside over the county courts. Each county would also have two associate justices with the traditional qualifications-local residency, experience, and integrity-but not necessarily with legal training. Associate justices could not hold court without one of their colleagues present. These acts also called for greater precision and uniformity in the county courts, "as far as the circumstances of the state will permit." ${ }^{55}$ The restructured county bench, henceforth dominated by professionals with legal education, gradually accumulated jurisdiction and power. An act of 1791, for example, gave the enhanced county bench a rudimentary equity jurisdiction in cases involving no more than one hundred pounds. ${ }^{56}$

By 1794 at the latest, an effort was underway to shift the balance of judicial power even more dramatically in the direction of the county courts by giving the county courts a monopoly on the holding of jury trials. ${ }^{57}$ This would entail either abolishing the General Court altogether or transforming it fundamentally into an appellate court. Any law that altered or abolished the General Court provided in the state constitution of 1776 would amount to a constitutional amendment and, to allow for an intervening election to ratify the will of the voters, had to be approved by two different sessions of the General Assembly. A bill to abolish the General Court passed both houses of the General Assembly in 1794, and again passed the House in 1795. But 
its ratification was stopped in the senate. ${ }^{58}$ This meant that a small group of conservative political veterans defeated the will of the much larger and more representative branch of the legislature. ${ }^{59}$

This failed initiative for further court reform had important links to a broader move to bring the legal system under the control of the legislature. The House also demanded in 1794 a definitive answer to the question of which part of British law was still in force in Maryland. A move to reform the testamentary laws brought this old problem to the fore. A general problem for the mid-Atlantic states, the reception problem was exacerbated in Maryland by Article 3 of the "Declaration of Rights" in the constitution of $1776 .{ }^{60}$ According to a complex formula involving tests of "usage" as well as chronology, Article 3 bound the courts of Maryland to observe English law and British statutes where Maryland law was silent or unclear. ${ }^{61}$ The exact formula to be applied by the judges was confusing, at best. In practice, the most learned lawyers and judges had difficulty pinning down exactly what was meant and could not produce a definitive list of British statutes and cases whose rules were binding. This ambiguity empowered Maryland's judiciary to be the final arbiters in many instances concerning the authority of English or British statutes and case law. ${ }^{62}$ In 1794 members of the House of Delegates complained that:

it is a badge and monument of former dependence that British statutes should be cited in our courts of justice, which convey, at the same time, the false and disgraceful idea that the citizens of Maryland are not competent to legislate themselves. ${ }^{63}$

The senate would not agree to this strongly democratic language, but drafted a comparable resolution with less inflammatory references to the ambiguities created by Article $3 .^{64}$ The legislature thus empowered a team of distinguished lawyers to settle the matter once and for all by drawing up an all-inclusive incorporation statute. But for reasons that remain unclear; the committee of 1794 did not complete its task, and the issue remained controversial. These jurisprudential concerns were related to the organization of the 
courts in several ways, not least through the issue of doctrinal uniformity and statutory control of the legal system.

The judiciary bill of 1801 continued the system of judicial circuits already in place. But it also limited the criminal jurisdiction of the General Court, increased the monetary threshold for the civil jurisdiction of the General Court from one hundred pounds to four hundred dollars, and reduced to three the number of justices on the Court of Appeals. Section 3 authorized the governor and his council to make the necessary appointments, a chief justice learned in the law for each of the five districts and two associate justices for each county. ${ }^{65}$ The law had conservative elements, however, designed to help insure passage; it carefully avoided repealing any explicit provision of Article 56 of the state constitution touching the General Court or Court of Appeals. ${ }^{66}$

Was the judiciary bill of 1801 truly a reform measure or merely a partisan, Republican attack on the largely Federalist judicial establishment? We can compare numerous rollcall votes in the House of Delegates, in particular, those in favor of the new judiciary act with those in favor of the radical new suffrage act enfranchising all adult white male Marylanders. Seventy to seventy-two delegates out of the eighty elected participated regularly in the session. On the final rollcall vote a large majority of forty-eight supported the radical extension of suffrage ${ }^{67} \mathrm{~A}$ much more modest working majority of thirty-eight voted in favor of a nearly final version of the judiciary bill, as amended by the senate. ${ }^{68}$ Of the thirty-eight delegates voting for court reform, all but four also voted for the broadening of suffrage. Of the fourteen opposed to democratic suffrage, all but one also opposed the judiciary bill. Five conservative delegates from heavily Federalist counties acquiesced to democratic suffrage, but opposed the judiciary bill. Even with abstentions and absences, the alignment was decisive: no delegate voting for the judiciary bill opposed the bill to radically extend suffrage, and no delegate voting against the radical suffrage bill favored the judiciary bill. ${ }^{69}$

These voting patterns reveal the strong connection be- 
tween the democratic movement and court reform, as well as the strengthening of party lines since the mid-1790s. The expansion of suffrage and the new judicial arrangement now formed part of a broad, identifiably Democratic-Republican legislative agenda. After 1800 a relatively coherent voting block on issues related to legal reform continued to exert its influence, though it occasionally lost a working majority, split into more conservative and more radical factions, or divided along lines of local interest.

\section{Abolition of the General Court}

The next major step for the reformers was the abolition of the General Court. Through the acts of 1790, 1791, 1796, and 1801 discussed above, the county courts were both strengthened and regionalized to a considerable extent. County courts now anticipated exclusive trial jurisdiction in most criminal matters and were presided over by a chief judge with legal training. But the General Court still threatened to dominate major litigation and retain its powerful supervisory discretion over doctrine and procedure. Furthermore, the justices of the General Court and their friends in the legislature could not be counted on to peaceably ratify the new arrangements, since many of the laws would automatically expire at some point and, as customary in this age, come up for renewal. Only eliminating the General Court altogether and restructuring the Court of Appeals would be likely to guarantee the preeminence of the local tribunals and anchor "the trial of facts" securely in the county courts. The effort took six years, and all did not go smoothly. Abolishing the General Court meant in effect, not simply making new appointments to judicial offices created by statute, but possibly removing judges with constitutional protection. Marylanders engaged in a heated debate over such a move at the state and national levels. ${ }^{70}$

In 1802 a bill to abolish the General Court was launched in the wake of the successful judiciary bill of the previous year. This 1802 bill, an "Act to alter, change and abolish, such parts of the constitution and form of government as 
relates to the establishing of a general court and court of appeals," narrowly passed, but failed to obtain the necessary ratification in 1803, as in the earlier attempt of 1794-1795. ${ }^{71}$ The bill would have made the local county courts virtually the only courts with an original jurisdiction in cases triable by jury. As in 1801, most delegates in favor of reorganizing the judiciary also voted in 1802 for electoral reforms, reallocating districts, and other measures designed to strengthen local government and democratize state government. ${ }^{72}$ Further analysis of voting suggests strong affinities among law reformers and democratic radicals. Ratification of the bill to abolish the General Court failed in 1803, twenty-eight in favor to forty against. ${ }^{73}$ Most of the twentyeight supporters of abolition were also on the losing side of a move to institute popular election of the governor, who was elected annually by the legislature. In 1804 and 1805 the third attempt to abolish the General Court was supported by many of the same delegates, who were again on the losing side of efforts to secure popular election of the governor, election of county fiscal officers, direct election of state senators, and other measures to strengthen democratic representation in state government. ${ }^{74}$

Evidence in the press and from other important testimony suggests that the coalition in favor of abolishing the General Court depended on the vote of a faction of moderates, mostly concerned about travel and related expenses. A detailed analysis of court costs and travel expenses involved in a typical suit appeared in the Republican Star or Eastern Shore General Advertiser on October 22, 1805. It showed that a citizen of Allegany County in far western Maryland could easily save seventy pounds on the costs of a suit and jury trial in his home county, a savings of about 76 percent over the same suit in the General Court at Annapolis, while a litigant from Worcester, on the Eastern Shore, might save over fifty-six pounds, a savings of 72 percent over the same suit in Easton.

Legal ideology was, nevertheless, important. The rank and file of Maryland politicians were not lawyers, much less philosophers of law. But they did have a basic vision of law 
and of courts, one that was perhaps typified by the views of Abraham Shriver. Shriver's father, David Shriver, Sr., was a veteran Maryland legislator at the center of Frederick County's Republican political machine. Abraham had recently been named an associate justice for the Frederick County district. His views have already been cited to illustrate the nature of partisan calculations on the Republican side, and they are revealing about legal ideology as well. ${ }^{75}$

As mentioned above, the 1802 act to abolish the General Court was not ratified and became a nullity the following year. But in January 1803 Shriver was extremely upset about the prospects of its passage because of a provision in Section 2 requiring two of the three justices appointed in any district to be learned in the law.

I do not mean that my dislike proceeds from any effect it can have on me, but that it proceeds from principle. I hate monopolies. I hate exclusive privileges; I think they are unbecoming the Genius of our Government. ${ }^{76}$

His further remarks manifested a simplistic, even mechanical view of judicial decision making and seethed with resentment against lawyers. He admitted it might be true that formally educated judges were "necessary on the appellate Courts." But in the counties, where it was already required that the chief judge be learned in the law, he believed this was unnecessary. If the individuals before the court lacked knowledge of the law, their lawyers could provide it. As for the need for the judges to untangle any possible ambiguities or conflict of laws, this was a matter of "the construction of ... language," which could be "understood, and Justly expounded tho the person has not been bred a Lawyer."77

Sure I am that characters can always be selected out of the mass of the people whose natural understandings are more vigorous, and whose acquired knowledge is often as extensive as are found in the General character of Lawyers-[laymen] who in fact will understand the use of language more critically and who will expound a paragraph with more ability than many... [a] Lawyer who in fact by nature was intended for the plow or Maul. What then is wanting, towards making such minds useful in expounding Law [i.e., 
from the bench], but a general knowledge of what is in force and what is not-of what applies to the question in dispute. ${ }^{78}$

Such remarks, as emotionally charged as they were, give a neat impression of the attitudes of a local magistrate towards lawyers and elite jurisprudence. Judges fit the facts to the letter of the law, which Shriver called "what is in force," and then used common sense to make their decisions. This vision denied that the learned tradition of law contained any hidden repository of wisdom or useful legal principles and embraced the democratic attitude that statute law was the law in its entirety. Along with this came a somewhat naive expectation about how law should function in practice-without doctrinal complexity and with little or no element of judicial discretion, much less policy making. In the early 1800 s, such attitudes helped justify the radical reform agenda and shape the substance of the specific initiatives. ${ }^{79}$

The debate made its way into the press. In view of the protracted effort to dismantle the General Court, the electoral contest that intervened between the General Assembly of 1804 and that of 1805 was particularly high-pitched. Based on early election results, a Republican paper on October 5, 1805, predicted an eight vote majority in the House for the measure abolishing the court. ${ }^{80}$ Opponents of the measure had campaigned against it during the elections. Some pointed out that the bill would require, ironically, the new appointment of a number of lawyers to the bench. Could enough qualified Republicans be found? Would such a reorganization really serve the interests of the people? The Baltimore American and Commercial Daily Advertiser carried a strident article in favor of the court reform bill, largely focused on this issue of new appointments. ${ }^{81}$ The article was ostensibly addressed to the "Executive" of Maryland, meaning the governor and council annually selected by the legislature, who would be responsible for making the judicial appointments. Rhetorically complex and politically sophisticated, the essay aimed at several audiences. It was designed in part to consolidate Republican support by threatening the possibility of public outrage if the measure failed. 
This evil [a defeat of the measure to abolish the General Court], great as it appears, is likely to be overcome[-] the republicans, adopting a line of conduct well calculated to defeat the nefarious designs of their foes, may render abortive the attempts of aristocrats to purloin the general rights of men under the garb of affection for a particular institution. ${ }^{82}$

The author also aimed to deflate the concerns of overly partisan Republicans by downplaying the problem of appointments and simultaneously to appeal to popular and radical supporters by stressing "simple and pure justice independent of law."

If there be not republican characters enough, of legal education, to fill the new stations, look around you for men among the mass of the people; investigate the quality of the understandings of those who now preside in our county courts in the situation of associates, and ascertain whether there be not among THEM minds well instructed in the laws of the land, in the rules of court, and the principles of equity, [well] calculated to sit as administrators of justice to their fellow citizens. Let it be a fixed principle that the chief judge shall be a man educated to the profession of the law, skillful in practice, wise by experience; and one, at least, of his associates, shall be a private gentleman, of good education, well read, of strong mind, and sound memory. Recollect that in the administration of justice there is a power given to the judges of deciding according to equity; remember that the rules of equity are not always best understood by lawyers. Their indiscriminate defence of right and wrong whilst in practice, as the immortal Junius observes, is calculated to lessen their perceptions of simple and pure justice independent of law. ${ }^{83}$

Thus, the author argued, a major reason for backing the reform was that it checked the hold of professional lawyers and legal technicalities over the courts.

A final resolution occurred in January of 1806 , when the General Assembly of 1805 passed an act to confirm the 1804 "Act to provide for the trial of facts in the several counties of this state, and to alter, change and abolish, all such parts of the constitution and form of government as relate to the general court and court of appeals." ${ }^{84}$ The new law altered the judicial districts slightly, increasing the number by one and creating a separate district for Baltimore and Harford 
counties, abolished the General Court and the nearly vestigial Court of Appeals, and created a new Court of Appeals composed of the chief judges of each of the six judicial districts.

In the end the attack on the General Court was not, in Maryland, simply a partisan attack on a Federalist bench, although important elements of party discipline were involved. Local jury trials were a genuine reform, and, for radicals, local justice meant loosening the hold of elite lawyers over the legal system.

\section{The Arbitration System}

The campaign to reign in the legal establishment in Maryland reached a peak of radicalism, rhetorically at any rate, in 1809 and 1810 . Two measures generated by the 1809 General Assembly provided a focal point. The first, referred to generically in the press as the fifty dollar act, adjusted upward the small debt jurisdiction of the justices of the peace. ${ }^{85}$ The second was an attempt to introduce a radical system of arbitration, to be available at the choice of either party, for the resolution of any civil litigation not cognizable by justices of the peace. ${ }^{86}$ The impact of the fifty dollar act is somewhat unclear; it supplemented older acts, notably one passed in 1791 for the "speedy recovery" of small debts "out of court." 87 The principal change was to increase the magistrate's jurisdiction out of court from ten pounds total debt and/or damages to fifty dollars, roughly twice as much. ${ }^{88}$ If the law had been enacted with the much higher ceiling of one thousand dollars called for by some, it would have been a radical change indeed. ${ }^{89}$ Even in its more moderate form, however, the law testifies to the widespread impatience with formal legal proceedings and the preference for simpler justice shared by many delegates.

The arbitration bill was potentially much more dramatic in its scope. In response to a petition from his constituents, George Harryman, a delegate from Baltimore County active in a range of legal reforms, sponsored the bill in $1809 . .^{90}$ The House record reads, "Mr. Harryman delivers a petition from 


\section{BY THE HOUSE OF DELEGATES, JANUARY 1, 1810.}

\section{ORDERED, That the Printer of the State be and he is hereby directed} to print with the Votes and Proceedings, for the consideration of the Pcople, An Act, entitled, An Act concerning Arbitrations, and for the more speedy Administration of Justice in this Slate.

By Order,
J. BREWER, Clk.

A Bill, entitled, An Act concerning Arbitrations, and for the more speedy Administration of Justice in this Statc.

$\mathrm{W}$ HEREAS reason sanctions the opinion, and experience justifies the belicf, that great defeds exist in the jodiciary system of this state, in as much as justice in many cases is delayed, owing to the great lengll of time required to travel through the mazes and intricacies of courts, and the heavy and ruinous axpensus inevitably atcendant thereon; and these being evils which loadly call for a remedy, thercforc,

It. Be it enactad, by the General Assembly of Morylund That from and after the first day of May, cighteca

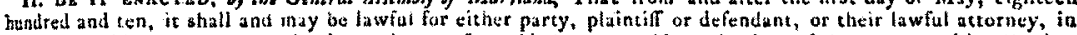
all aclions which may not, on the day and year aforesaid, be cognizable by justices of ene peace, and in all uther civil actions or suits whatever, which andy be brought in any court of this atate afier the first day of May next, to enter at the cleck's offee in the county where the defendunt revidss, a rule of reterence, wherein the said paty shall state his, her or their determination, to have arbitrators chosen on a day certain. to be mentioned therein, which day shall not be more than thirty days from the time of entering their determination aforesaid, for bearing and determining all maters in variance berween the partics in such ouit or action. which rule shall be entered on record by the clerk, and the following proceedings shall be had thereon; that is to say, the party entering the rule of reference shall procure from the clerk a copy thereof, wader his hund and seal, and shall, by some disinterested person. within ten days theresfet, serve the same, or a copy thereof, on the opposite party, his, her or their agent or attorney, or if not to be found, loave a copy thereof at his, her ur their last piret of aboile, giving at least ten days notice in the city of Baltimore of the day when the arbitrators are to be chosen, and at least fftecn days notice of such time in each and eviry county of this atate, and the proof of aervice shall be the oath or affrmition of the person setving the same.

III. AND Es IT ENACTED, That where both parties attend, either by themselves, their attornies or agents, before the clert, the artitracora sball be ctosen in the following monner, to wit: 'The parnies having first agreed as to the number of arbitrarors, or in case of disagreament, the number shall be fixed by the clark, which ahall to either three, five or seven, the pleintiff shall, in the first place, nominget one person if the number fixed upan be three, two if the number be five, and three if the number be seven, if all or either of them be objected" to by the defendant, the plaintiff shall nominate other persom in the place of those objected to. until he numiates to the number of six persons for each and every person allowed to be by him nominated, and the same grivilse shall be criven so the defendant, and the like right to object extended to the plaintiff, but if it stiontd o hoppen that both or either of the parties ahould objed to a greater number of persuns than is above stated. in that case the arbitrators shall be appoinced in the same manner as is herein afier disected where one of the parties neglefis to atcend on the day appointed for selecting the arbitrators, bat in case the pyrtits agree in the cigice of arbitrators as above dirseded, the ampire shall be closen in tha folluwing nanuer, via. The partics shall nomiate alternately, (be zinning with the plaintif,) seven persons. wish liberiy given to cach, or either of

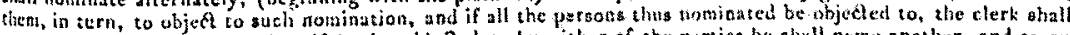
name a persun fur the umpire, if he be objeded to by either of the parties he shall name another, and ao on catil tie a) arbitrotors foel upon be thee, five if the nomber be five, anil seven if the number be seven, the parties ohall

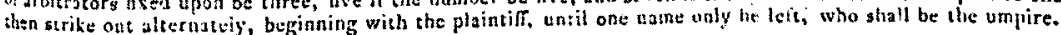

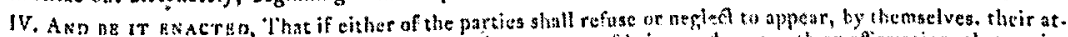
toraty or agzt, on the day appointed, to choose arbitrators, proof being nide, on oulh or aflirmation, that notice

The proposed arbitration bill, 1809-1810, was tabled at the end of the 1809 legislative session. The House Speaker ordered it printed then, but it was not revived in the 1810 legislative session. (Courlesy Maryland Historical Society, Baltimore) 
sundry inhabitants of Baltimore County, praying an arbitration system; which was read and referred to [a committee of] Mr. Harryman, Mr. Brown, Mr. Archer, Mr. Randall, and Mr. Brent to consider and report thereon." 91 The committee quickly produced a bill, but could not gather much support for it. Towards the end of the session, on New Year's Day 1810, Harryman moved to have the bill referred to the next General Assembly. No division of the votes was called for. Stevenson Archer moved that the bill be printed and publicly distributed, and it was so ordered by the Speaker. ${ }^{92}$

The origins of the idea for the system of arbitration outlined in the Maryland bill remain obscure. Historians have detected a variety of procedures involving arbitrators in several colonies during the eighteenth century, notably within commercial communities and the communities of religious minorities, such as the Quakers, and ethnic minorities, particularly Dutch and German. ${ }^{93}$ Bills with provisions similar to Maryland's were introduced in Kentucky in 1795 and in Pennsylvania during the Republican era there. ${ }^{94}$ But little is known about actual practices. Except when it occurred directly under the supervision of a court, to settle a boundary dispute for instance, arbitration was unlikely to leave a record. Widely scattered legislative bills and other evidence confirm that elements within Jeffersonian Republicanism were pushing arbitration as an alternative to wasteful, expensive litigation. In 1804 a series of essays outlining a broad Republican agenda for action in state legislatures appeared in the regional paper of western Maryland, The Maryland Herald, and Hager's-Town Weekly Advertiser. ${ }^{95}$ This happened in August, September, and October, as the state was preparing for elections. ${ }^{96}$ The fourth essay attacked the inefficiency and injustice of prevailing legal procedures and defended legal arbitration against the charge that it undermined the constitutional right of trial by jury. ${ }^{97}$ The tone was extremely radical. The author railed against the oppressiveness of the existing regime of property law, dramatized the great cost of "lawyerizing" the collection of small debts, and admonished readers to keep the right to trial by jury in proper perspective. ${ }^{98}$ 
Maryland's arbitration proposal would have allowed any civil complaint to be determined altogether outside the courts. A panel of arbitrators evenly selected by the parties would hear the evidence and make a determination. The arbitrators would have summoning powers to gather evidence and hear witnesses and would make a formal decision. If either party then rejected the settlement, he could appeal to the courts, but if he failed to win a judgment more favorable than the arbitration settlement, he paid the legal costs of his opponent as well as the original award and a per diem penalty for the delay.

While support for the arbitration system was apparently slim in the legislature, it became a focal point for vicious electioneering in 1810 in some central Chesapeake counties. A campaign in the Republican press generated vituperative diatribes against lawyers, highlighting their alleged offensesfrom holding themselves superior to others to self-dealing as members of the legislature. ${ }^{99}$ In July, August, and September 1810, in anticipation of the October elections for a November session of the General Assembly, the Republican Star or Eastern Shore General Advertiser ran a series of articles debating the virtues and vices of the legal establishment and the lawyers supporting it. One group of local politicians tried to stir up anti-lawyer sentiment, while another tried to neutralize it.

On July 3 the local Democratic-Republican party leaders published their intention of holding district committee meetings to select a slate of suitable candidates for office. ${ }^{100}$ Opponents criticized the move as an undemocratic effort to manipulate the electorate. Democratic-Republicans defended it as a means to guarantee that the voice of the people would have a chance against the interests of wealth and privilege. "Crito" published a letter "To the Democratic Citizens of Queen Ann's County" defending the committee plan; he then went on to praise the record of lawyers in the Maryland legislature and attack what he termed "our office-hunting Anti-Lawyer men." 101 "Cato" returned fire, castigating lawyers for their hypocrisy, self-dealing, and use of the General Assembly to pass laws raising themselves 
above their constituents to the disadvantage of the public. ${ }^{102}$ Another letter addressed to the "Democratic Citizens of Queen Ann's County" from "No Office Hunter" criticized lawyers for self-dealing in the legislature and attacked the record of a particular incumbent. ${ }^{103}$ In the same paper, a stridently partisan letter to the "Democratic Citizens of Caroline County" described the fifty dollar act and the arbitration system as measures in the interests of the people that lawyers would naturally try to undermine. Seeking to make the clearest possible connection between his anti-lawyer stance and his political views in general, the author claimed he could tolerate a true "federal man," but could not abide "tory scum" such as the "sheep sheering Pinkney." 104 Another letter to "The Democratic Citizens of Caroline County" defended the Republicans' record of law reform, promoted the arbitration system, and satirized the learned legal tradition. ${ }^{105}$ "A Voter of Caroline County" further attacked the record of lawyers in the state legislature and promoted the arbitration system, which was now a significant issue in the campaign. ${ }^{106}$ On August 14 and September 4, "Crito" published further responses to "No Office Hunter" and "Cato" in which he defended the record of lawyers in the legislature and criticized arbitration as dangerously subversive of law and of that bulwark of liberty, trial by jury. ${ }^{107}$

Throughout all this, the author promoting the system of arbitration amplified the anti-lawyer theme in several ways. His final piece, a lengthy harangue of over five full columns, took lawyers to task for their ill-considered use of precedents, ridiculous rules of pleading, artificial rules of evidence, and degradation of trial by jury into a game of chance. ${ }^{108}$ Defending lawyers, "Crito" argued that they made good legislators because they knew the law and therefore knew which ones needed to be changed. ${ }^{109}$ His opponents complained, however, that a chief contribution of lawyers in the legislature was passing laws written in language that was generally unintelligible. ${ }^{110}$ "Crito" conceded that his views might "rouse into action the herd of anti-lawyer men," but wished to point out that disregarding the skill of lawyers 
might be foolish. He claimed that many authorities, including Blackstone, had found it strange that knowledge and experience are valued in most professions, while for some reason every common man who has raised himself up in society with a little good luck fancies himself a competent legislator." $"$ 'l

At least as important as the content of these exchanges about lawyers was the tone which each writer projected. "Crito" emphasized his knowledge of the actual workings of Maryland government in carefully slanted and somewhat patronizing language. He punctuated it with sarcastic references to "Bonapart" and dictatorial rule-the implied result of too much democracy-and similar rhetorical devices. His opponent used strongly anti-aristocratic rhetoric, frequently resorted to ad hominem argument, and employed highly abusive language to portray "Crito" as a pompous fraud, an incumbent officeholder uninterested in the public welfare, aiming only to perpetuate the strangle hold of lawyers over Maryland government and society. Only lawyers, he alleged, had so arranged it through the legislature that they could have their fees collected by the sheriff without the full process of debt law. ${ }^{112}$

The results of such campaign rhetoric are, of course, impossible to measure exactly. The Democratic-Republicans carried the elections of 1810 as they had in 1809 , winning a comfortable majority in the House of Delegates and sweeping the delegations from Maryland's central counties and Baltimore.

The 1810 session of the legislature was highly politicized and included abundant opportunities for delegates to express their hostility towards lawyers, the legal establishment, and the learned tradition of law. Theodorick Bland, later Chancellor of Maryland, had been reelected as a Republican delegate from Baltimore. He was leading a campaign on the part of local banking interests against the Bank of the United States. Stevenson Archer led a move in the House to impeach the two associate justices of his district. During the same session the chancellor, William Kilty, submitted a detailed report on the use of English and British statutes in Maryland. ${ }^{113}$ 
Associate Justices Thomas Jones and Zebulon Hollingsworth, an old Federalist, survived the attempt to remove them for dereliction of duty. ${ }^{114}$ The vote to remove Jones was close. The House voted forty-six to twenty-five against him, just shy of the constitutionally required twothirds majority needed to forward the petition to the governor. ${ }^{115}$ The fate of Kilty's report, which had been commissioned by the legislature during a previous session, also presents ambiguities. On the floor of the House, Bland generously praised the meticulous work but implied that it was still incomplete. ${ }^{116}$ After Bland's recommendation, the Report was published, but never officially adopted by the legislature. ${ }^{117}$

With all of these other law-related issues on the agenda, legislators apparently had little inclination to consider the arbitration system. As the 1810 session was drawing to a close, with no action yet on the arbitration bill, The Maryland Republican carried a dialogue between a "Lawyer" and a "Parson," crafted by a radical reformer hoping to spur the legislature into action. ${ }^{118}$ Like the earlier pieces on the arbitration issue in the Eastern Shore paper, this one also attacked the legal profession generally. With considerable skill, the Parson developed an elaborate portrait of lawyers as privileged insiders dedicated to undermining justice rather than serving the public. His particular themes included 1) the ways in which lawyers had corrupted trial by jury, a legal form much more ancient than their profession, and 2) the elaborate rules for the exclusion of evidence "introduced by lawyers and judges... not by any legislatures ... to enhance their profit by the mystery of the craft." 119 The Lawyer responded that his colleagues were renowned for "their extensive reading, deep-thinking, and close reasoning" and had helped secure a system of government designed to protect individual liberties, providing Americans with the greatest government on earth. ${ }^{120}$ The Parson answered this claim with a simple but powerful statement encapsulating the radical anti-lawyer view of the matter.

The excellence of our government arises from having destroyed the established monarchy, aristocracy, and hierarchy of England and 
leaving the people free to govern themselves. But you lawyers still ride us. Now if you will only be so good as to let us do our own law business, as we do the rest, then indeed we may well boast that we have the best govermment on earth. ${ }^{12}$

There was no revival of the arbitration bill, but the campaign in 1810 dramatized many issues surrounding legal reform from the perspective of those who wanted more than mere pragmatic, piecemeal adjustments. The radical perspective emanated from a profound distrust of the legal establishment centered on the belief that professional lawyers used the old-regime tricks of their elitist fraternity to corrupt the purpose of the law.

\section{Conclusion}

The anti-lawyer campaign had a distinct agenda in the 1790-1810 period in Maryland. As elsewhere, notably Pennsylvania and Kentucky, its various initiatives permeated state politics for more than a decade. The movement was supported by a variety of ideologies, including radical hostility to the use of law and government to create economic advantage and social inequality. Law reform was embraced by localists, Democrats, Republicans, and moderate to conservative reformers. The latter camp included some leading lawyers and entrepreneurs committed, in their own words, to the "speedy administration of justice," but with little interest in radical experiments with debt law or systems of arbitration. Such men were knowledgeable about courts and familiar with the strengths and weaknesses of traditional and formal procedures. From their perspective, the legal profession was to be controlled, not eliminated. During the Republican era in Maryland, these moderates nevertheless depended upon support from Democrats and radicals to get elected, stay in office, and pass legislation. The Republican political elite treated the anti-lawyer agenda with care as it harnessed and tamed those who aimed more squarely at demystifying the law and dismantling the monopoly of the legal fraternity.

Such dynamics point to a pervasive distrust of the legal 
establishment hidden beneath the moderate compromises that in fact became law and dominated legal development. We now know that in at least four states anti-lawyer radicalism, based on resentment of the professionals' monopoly and antipathy towards procedural technicalities, was a significant factor in the early national political process. Radical attacks on the common law tradition, while extreme, were less marginal and more widespread than has generally been suggested. Radical authors, such as Pennsylvania's Benjamin Austin, articulated a significant dimension of early American legal culture. ${ }^{122}$ Such views may well have represented an undereducated, localist perspective, but did not represent a hollow fanaticism.

The coherence of anti-lawyer sentiment suggests a further conclusion. Some of the most important long-term continuities in our legal tradition have apparently survived only by being persistently maintained and defended in the political sphere. We need to take up much more earnestly the theme that legal culture interacts with society and the legislative process in unique ways. ${ }^{123}$ This approach does not reject social, economic, and intellectual perspectives on the law. It simply calls for more careful study of the political dimensions of legal development. Lawyers have built and defended their powerful tradition in the public sphere as well as in courtrooms and professional writings. 


\section{Endnotes}

* The author would like to thank David Konig, James Rice, and John Mayfield for their comments on earlier drafts of this article, the staff of the Maryland Historical Society, and Marlene Magness of the Historical Society of Harford County.

1. Robert Post, "On the Popular Image of the Lawyer: Reflections in a Dark Glass," California Law Review 75 (1987): 379-389.

2. Maxwell Bloomfield, American Lawyers in a Changing Society (1976), 44.

3. Richard E. Ellis, The Jeffersonian Crisis: Courts and Politics in the Young Republic (1971), 123, 175, 198.

4. Shannon Stimson, The American Revolution in the Law (1989) (on the broader implications of the attachment to trial by jury); A. G. Roeber, Faithful Magistrates and Republican Lawyers: Creators of Virginia Legal Culture, 1680-1810 (1981) (on the struggle between "Court" and "Country" attitudes towards the law); Stephen B. Presser, "A Tale of Two Judges: Richard Peters, Samuel Chase, and the Broken Promise of Federalist Jurisprudence," Northwestern University Laiu Review 73 (1978): 26111 (on conservative legal ideology); Stephen B. Presser and Beckey Bair Hurley, "Saving God's Republic: The Jurisprudence of Samuel Chase," University of Illinois Law Review, 1984: 771-822 (on conservative legal ideology). See also David Lieberman, The Province of Legislation Deter. mined: Legal Theory in Eighteenth-Century Britain (1989) (on the changing theoretical framework for statute law in relationship to common law during this period).

5. An Act for amending and reducing into a system the duties and regulations concerning last wills and testaments, $1798 \mathrm{Md}$. Laws ch. 101; An Act respecting the punishment of criminals, 1793 Md. Laws ch. 58; An Act concerning crimes and punishments, 1809 Md. Laws ch. 138. On the modernization of punishment, see Jeffrey K. Sawyer, "'Benefit of Clergy' in Maryland and Virginia," American Journal of Legal History 33 (1990): 49, 65. On jury trials, see pp. 13-14, 17-22 infra.

6. An Act concerning the amendment of judicial proceedings, 1809 Md. Laws ch. 153 (allowed amended pleas in an effort to stop suits from being dismissed for technical problems in pleading).

7. See p. 22 infra.

8. Lawrence M. Friedman, "Law Reform in Historical Perspective," St. Louis University Law Journal 13 (1969): 351-372 (explores the varied meanings of "reform" in such a context).

9. Norman K. Risjord, Chesapeake Politics, 1781-1800 (1978), 476$478,545-546,565-572$ (emphasizes the partisan alignment of voting blocks in state legislatures). See also Whitman H. Ridgway, "Community Leadership: Baltimore During the First and Second Party Systems," Maryland Historical Magazine 71 (1976): 339, 334-348 (emphasizes the 
basic social continuity among the interlocking elites of this period-the dominant type of politician in the emerging Republican party, General Samuel Smith, was "from the same class as many of his Federalist counterparts"); p. 9 infra.

10. Roeber, Faithful Magistrates, supra note 4, at 160, 192; James W. Gordon, "The Popular Image of the American Lawyer: Some Thoughts on its Eighteenth and Nineteenth Century Intellectual Bases," Washing. ton and Lee Law Review 46 (1989): 763-806.

11. See John Warr, The Corruption and Deficiency of the Lawes of England Soberly Discovered: or Liberty Working up to its Just Height (1649), excerpted in Divine Right and Democracy: An Anthology of Political Writing in Stuart England, ed. and intro. David Wootton (1986), 148, 158.

12. Nancy L. Matthews, William Sheppard, Cromwell's Law Reformer (1984), 145 (Sheppard's system would have simplified debt law and relocated much judicial power in the county courts; his popular legal writings were widely published).

13. Donald Veall, The Popular Movement for Law Reform, 1640-1660 (1970), 98, 225 (describes five postures towards law reform among political radicals in seventeenth century England and summarizes essential differences between pragmatists and radicals).

14. Stuart E. Prall, The Agitation for Law Reform during the Puritan Revolution, 1640-1660 (1966), 71 (a work to be used with caution due to its overly schematic view of "Puritan" thought).

15. Isser Woloch, "The Fall and Resurrection of the Civil Bar, 17891820s," French Historical Studies 15 (1987): 241, 244, 247, 249 (The barristers' monopoly on pleading was abolished in 1790; most formalities of civil procedure and the office of advocate were abolished in 1793 . By 1796 the profession was being rehabilitated for the public good.)

16. See pp. 25-28 infra.

17. Baltimore American, Nov. 29, 1805 (italics in the original).

18. Id. (italics in the original).

19. Dennis R. Nolan, "The Effect of the Revolution on the Bar: The Maryland Experience," Virginia Law Review 62 (1976): 969, 981 (argues that the post-revolutionary Maryland bar was particularly distinguished). See also Alan F. Day, A Social Study of Lawyers in Maryland, 1660-1775 (1989) (a detailed survey of known practitioners confirming the wealth and power of the legal elite).

20. Bloomfield, American Lawyers, supra note 2, at 40, 43.

21. Presser, “A Tale of Two Judges," supra note 4, at 72-80, 88111; Presser and Hurley, "Saving God's Republic," supra note 4, at 771822.

22. Dr. John Archer to Benedict E. Hall, Jan. 3, 1802, Archer Family Papers, Ms. Collection, Harford County Historical Society [hereinafter, Archer Papers] (suggesting that a purpose of the Alien and Sedi- 
tion Acts was to create business for an enlarged federal judiciary).

23. Charles M. Cook, The American Codification Movement: A Study of Antebellum Legal Reform (1981) (notes the resistance of the legal profession to reform and codification in America); Matthews, William Sheppard, supra note 12, at 145, 186-188 (in the politically radical Parliament of 1656, lawyers ostensibly loyal to Cromwell but protective of the legal status quo, such as Bustrode Whitelocke, blocked radical law reform); Veall, The Popular Movement, supra note 13, at 225 (ideological differences among reformers); Prall, Law Reform, supra note 14, at 35, $60,73,113$ (on the conservatism of the leading members of the English bar).

24. In the 1794 session of the assembly, for example, a series of law-related votes shows only weak correlations among the delegates' commitments to 1) abolish the General Court, 2) codify Maryland's testamentary laws and adequately compensate the lawyers doing the work, 3) abolish taxes on legal paper work and eliminate fees collected by justices of the peace, and 4) enlarge the equity powers of county courts. 1794 Votes and Proceedings of the General Assembly of Maryland, House of Delegates, 25, 32, 58 [hereinafter, Votes and Proceedings, House].

25. Ellis, Jeffersonian Crisis, supra note 3, at 19, 123, 157 (nationally and in Kentucky and Pennsylvania); Risjord, Chesapeake Politics, supra note 9, at 181 (suggesting similar patterns for North Carolina, Virginia, and Maryland); Elizabeth K. Henderson, "The Attack on the Judiciary in Pennsylvania," Pennsylvania Magazine of History and Biography 61 (1937): 113-136 (a detailed account based on the votes and proceedings of the Pennsylvania legislature, 1800-1810).

26. Samuel Chase's Grand Jury Charge Book, Ms. 2568, Maryland Historical Society (see pp. 10-11 for a harangue against the idea of "natural rights"). See Haw, Beirne, Beirne, and Jett, Stormy Patriot: The Life and Times of Samuel Chase (1980), 172, 177-208.

27. Charles Carroll of Carrollton, August 27, 1800, in Ridgway, "Community Leadership," supra note 9, at 337.

28. Thomas Jefferson, Notes on the State of Virginia, ed. William Peden (1982), 118.

29. John Archer to Robert Archer, Sept. 17, 1799, Archer Papers.

30. John Archer to Hall, Dec. 8, 1801, Jan. 3, 1802, Archer Papers. Archer, a political veteran, had served in Maryland's Constitutional Convention of 1776 (where he cast several anti-lawyer votes) and was subsequently a frequent state delegate and three-term U.S. congressman; A Biographical Dictionary of the Maryland Legislature, 1635-1789, ed. Edward Papenfuse, et al., 2 vols., $(1979,1985), 1: 107$.

31. Edward G. Roddy, "Maryland and the Presidential Election of 1800," Maryland Historical Magazine 56 (1961): 244-268; J. R. Pole, "Constitutional Reform and Election Statistics in Maryland, 1790-1812," Maryland Historical Magazine 55 (1960): 275-292. See also Ridgway, "Commu- 


\section{Georgia Journal of SOUTHern Legal History}

nity Leadership," supra note 9, at 334.

32. Pole, "Constitutional Reform," supra note 31, at 275, 280. The devastating effect on free African-Americans has been demonstrated recently by David S. Bogen, "The Annapolis Poll Books of 1800 and 1804: African-American Voting in the Early Republic," Maryland Historical Magazine 86 (1991): 57.

33. Pole, "Constitutional Reform," supra note 31, at 277 (between 1790 and 1810 the population of Baltimore grew 244 percent).

34. Id. at 279.

35. Roddy, "Maryland and the Presidential Election," supra note 31, at 352 .

36. Ridgway, "Community Leadership," supra note 9, at 337.

37. William Pinkney to Ninian Pinkney, July 21, 1801, Pinkney Papers, Ms. 1388, Maryland Historical Society. William, a leader of the Maryland bar, was acting as Maryland's agent in London at the time in a complicated suit to recover stock in the Bank of England. Biographical Dictionary, supra note 30, at 2:648. Ninian, an entrenched Federalist, served as a clerk for the state senate in Annapolis.

38. William Pinkney to Ninian Pinkney, supra note 37.

39. Id.

40. Id. (The numbers in brackets have been added. Spelling and punctuation have been modemized and abbreviations spelled out.)

41. An Act relative to the administration of justice in this state, and to repeal the acts of assembly therein mentioned, $1801 \mathrm{Md}$. Laws ch. 74.

42. Carroll T. Bond, The History of the Court of Appeals of Maryland (1928), 58.

43. "Constitution and Form of Government," in A Decisive Blow is Struck, ed. Edward C. Papenfuse and Gregory A. Stiverson, (1977), Art. 56 (a facsimile edition of the proceedings of Maryland's constitutional convention, with introduction).

44. The General Court's original jurisdiction was limited in 1785 to cases involving one hundred pounds or more, "current money," that is, denominated in any legally recognized currency at the official rate of exchange. 56.

45. "Constitution and Form of Government," supra note 43, at Art.

46. 1794 Votes and Proceedings, House, 68-69. (Five judges originally constituted the Court of Appeals. The first two vacancies were left unfilled. A House committee thought that three judges were sufficient, and that any two might decide a case.)

47. Contemporary observers stressed this inconvenience. See Pinkney's reference to "distance," p. 11 supra; Roger B. Taney, Memoir 
of Roger Brooke Taney, ed. Samuel Tyler (1872), 57. [I thank James Rice for calling this passage to my attention.] See also pp. 11, 8 infra.

48. Kermit L. Hall, The Magic Mirror: Law in American History (1989), $65-75$.

49. Id. at 75; 1 U.S. Statutes at Large 73 (1789); The Proceedings Relative to Calling the Conventions of 1776 and 1790. The Minutes of the Convention that Formed the Present Constitution of Pennsylvania,... The Constitutions of 1776 and $1790, \ldots$ (1825), 155.

50. Roeber, Faithful Magistrates, supra note 4, at 192, 203.

51. Wythe Holt, "'To Establish Justice': Politics, The Judiciary Act of 1789, and the Invention of the Federal Courts," Duke Law Journal (1989): 1477; Akhil Reed Amar, "The Two-Tiered Structure of the Judiciary Act of 1789," University of Pennsylvania Law Review 138 (1990): 1499.

52. See pp. 17-18 infra. General Samuel Smith, an ardent Jeffersonian, defended the repeal; "Speech of Gen. S. Smith," a broadside, Maryland Historical Society. Another Marylander, Federalist John Dennis, was a principal opponent of repeal. Cf. John S. Pancake, Samuel Smith and the Politics of Business: $1752-1839$ (1972), 65. A letter from John Archer to Benedict Hall, Feb. 18, 1802, Archer Papers, discussed in detail arguments concerning the statutory and constitutional status of judicial tenure under U.S. and Maryland law.

53. Abraham Shriver to Andrew Shriver, January 8, 1802, Shriver Family Papers, Ms. 2085 Box 2, Maryland Historical Society [hereinafter, Shriver Papers.] [I wish to thank James Rice for the suggestion to explore the Shriver Papers in this connection.]

54. $1790 \mathrm{Md}$. Laws ch. 33; An Act for the better administration of justice in the several counties of this state, $1796 \mathrm{Md}$. Laws ch. 43.

55. 1790 Md. Laws ch. 33, sec. 1; 1796 Md. Laws ch. 43, sec. 1.

56. An act respecting the equity jurisdiction of the county courts, $1791 \mathrm{Md}$. Laws ch. 78 (The enactment sought to preserve, however, traditional boundaries between "law" and "equity" and forbade bringing equity suits in these courts for the purpose of "compelling a specific performance of any agreement.")

57. An act concerning the jurisdiction of the general court, 1794 Md. Laws ch. 55.

58. Id.; 1795 Votes and Proceedings, House, 89.

59. The fifteen state senators were indirectly elected, and any eight of them could block a bill. The eighty members of the House of Delegates were directly elected-four from each county and two each from Baltimore and Annapolis.

60. "Declaration of Rights," in A Decisive Blow, ed. Papenfuse and Stiverson, supra note 43, at Art. 3 . Eleven of the thirteen original states made some provision for the use of common law and British statutes, 
but how they accomplished this varied considerably; cf. Elizabeth Gaspar Brown, British Statutes in American Law, 1776-1836 (1964), 24.

61. "Declaration of Rights," in A Decisive Blow, ed. Papenfuse and Stiverson, supra note 43. "That the inhabitants of Maryland are entitled to the common law of England, and the trial by jury, according to the course of that law, and to the benefit of such of the English statutes, as existed at the time of their first emigration, and which by experience have been found applicable to their local and other circumstances, and of such others as have been since made in England, or Great-Britain, and have been introduced, used, and practiced by the courts of law or equity; and also to all acts of assembly in force on the first of June seventeen hundred and seventy-four." Id. at Art. 3.

62. The gradual, selective reception and modification of English law in Maryland was a complex, intricate process, and I have intentionally omitted it from this discussion. It is the focus of another paper, Jeffrey K. Sawyer, "Comparing Legal Cultures: Towards A New Method?" presented to the American Society for Legal History, Chicago, October 19, 1990, currently being revised for publication under the new title, "Logic or Experience? The Life of the Law in Early Maryland."

63. 1794 Votes and Proceedings, House, 72.

64. Id. at 89; 1794 Votes and Proceedings, Senate, 36.

65. $1801 \mathrm{Md}$. Laws ch. 74 , supra note 41 .

66. Its constitutionality was challenged in Whittington v. Polk, 1 Harris \& Johnson 236 (1802). William Polk of Somerset County had been named to replace William Whittington, an associate justice in Worcester County. Whittington sued on a writ of novel disseisin to recover his office, and the court granted a jury trial. Following the trial, at which the jury returned a special verdict finding that Whittington had been removed in a manner consistent with the legislative acts, the court ruled that the Act of 1801 was constitutional (from both a state and federal perspective) and that the writ did not lie; id. at 242, 249. Jeremiah $T$. Chase, chief justice of the General Court, discussed the propriety of such judicial review in language resembling that taken up a year later by John Marshall in a similar case, Marbury v. Madison, 5 U.S. (1 Cranch) 137 (1803).

67. 1810 Votes and Proceedings, House, 51.

68. Id. at 103. Final passage was by voice vote.

69. Seventeen delegates abstained or were absent for one or the other vote. Most conspicuously, a group of eight, apparently absent for the vote on the judiciary bill, favored the extension of suffrage, and a group of five, including three from conservative Dorchester County, voted against the judiciary bill, but did not cast a vote on the suffrage bill.

70. See pp. 13-14 supra; note 52 supra. 
71. $1802 \mathrm{Md}$. Laws ch. 198; 1803 Voles and Proceedings, House, 58.

72. 1802 Votes and Proceedings, House, 83.

73. 1803 Votes and Proceedings, House, 58.

74. 1804 Votes and Proceedings, House, 68, 72, 79-80, 85.

75. Abraham Shriver to Andrew Shriver, January 21, 1803, Shriver Papers; see also note 53 supra.

76. Abraham Shriver to Andrew Shriver, January 21, 1803, Shriver Papers. Although he suggested the contrary, the provision might well have cost him his appointment. For while he fancied himself a man of the law, his own letters provide evidence that he was not taken very seriously by the leading citizens of his county.

77. Id.

78. Id. Shriver concluded this section of his letter by confessing, "I am disturbed and cannot proceed-You will however comprehend the Ideas I have on this subject."

79. I am not suggesting that Shriver was a deeply committed radical egalitarian, although he used such language. He appears more concerned with his own and his family's fortunes than with anything else and seems just as prejudiced against the laboring classes as against lawyers. He was very attached to his status as an associate justice and pleased to have the income provided by the four dollars per diem for attending court.

80. In fact, the ratification passed the House by only five votes.

81. Baltimore American, Nov. 13, 1805.

82. Id. (italics in the original).

83. Id.

84. 1805 Md. Laws ch. 16; 1804 Md. Laws ch. 55. See also An Act to provide for the organization and regulation of the courts of common law in this state, and for the administration of justice therein, $1805 \mathrm{Md}$. Laws ch. 65 (which augmented the institutional reforms with necessary procedural changes governing such matters as jurisdiction and appeal).

85. A Supplement to the act, entitled, an act for recovery of small debts out of court, and to repeal the acts of assembly therein mentioned, 1809 Md. Laws ch. 86.

86. A Bill, entitled An Act concerning Arbitrations, and for the more speedy Administration of Justice in this State, sec. II, a printed copy, bound with 1808-1810 Votes and Proceedings, House and Senate, Maryland Historical Society.

87. An Act for the speedy recovery of small debts out of court, and to repeal the acts of assembly therein mentioned, $1791 \mathrm{Md}$. Laws ch. 68.

88. The dollar was converted at the rate of seven shillings, six pence, or $\$ 2.66$ to the pound. Compensating for depreciation of the cur- 
rency, the 1809 act may have simply set the limit nearer to where it had been in 1791. For Maryland's currency laws, see An Act to adjust the debt due from this state, $1781 \mathrm{Md}$. Laws ch. 17.

89. 1809 Votes and Proceedings, House, 60-62. The one thousand dollar limit was easily defeated, two in favor and fifty-seven opposed. A one hundred dollar limit met stiff resistance, with only nine in favor and fifty-one opposed. The bill passed in its final form, with the fifty dollar limit, thirty-seven to twenty-two.

90. 1809 Votes and Proceedings, House, 63.

91. Id. at 63. Mr. Brown was probably Moses Brown of Baltimore County rather than James Brown of Queen Anne's. Beale Randall was also a Baltimore County delegate. Stevenson Archer, a well-trained lawyer, had inherited his father's place of political influence in Harford county and was a leader for democratic and legal reform in the legislature. William L. Brent was a Republican delegate from Washington County.

92. Id. at 96. The Speaker, Tobias E. Stansbury, was also from Baltimore County. A copy of the bill was thus preserved. See note 86 supra.

93. Bruce H. Mann, Neighbors and Strangers (1987), 126-136 (commercial arbitration practices in colonial Connecticut); Jerold S. Auerbach, Justice Without Laws (1983), 27-46 (early evidence of alternative dispute resolution in other colonies).

94. Ellis, Jeffersonian Crisis, supra note 3, at 137-38; Henderson, "Attack", supra note 25, at 121, 131, 135. In the Pennsylvania legislature an arbitration bill was introduced and passed during the 1802-1803 session, but the governor vetoed it. The issue was fought over repeatedly in subsequent years until a law was finalized during the 1809-1810 session-albeit a watered-down version with a claim limit of one hundred dollars.

95. Allegedly reprinted from the National Intelligencer, a Washington, D.C., paper.

96. The Maryland Herald, and Hager's-Town Weekly Advertiser, Aug. 22, Sept. 4, 19, 26, Oct. 3, 1804.

97. Id., Sept. 4, 26, 1804. "Letter Fourth" appeared in two installments.

98. These were core issues for the seventeenth century English reformers: see Matthews, William Sheppard, supra note 12, at 166 (reform of small debt law), 163 (jury trial reform and alternative modes of trial); Prall, Agilation for Law Reform, supra note 14, at 60.

99. The prospect of losing control of the state legislature created a degree of panic among Democratic-Republicans; the Federalists had regained marginal control of the House in the election of 1808 .

100. Republican Star or Eastern Shore General Advertiser, July 3, 1810.

101. Id., July $17,1810$. 
102. Id., July 31, 1810 .

103. Id., Aug. 7, 1810 (the incumbent was left unnamed).

104. Id. The reference is probably to William Pinkney, an anglophile whose successful legal and diplomatic career generated substantial fees.

105. Id., Aug. 14, 1810.

106. Id., Aug. 21, 1810.

107. Id., Sept. 4, 1810.

108. Id., Oct. 9, 1810.

109. Id., Sept. 4, 1810.

110. "A Voter of Caroline," id., Aug. 21, 1810.

111. Id., Sept. 4, 1810.

112. "Cato," id., July 31, 1810. "Crito" attempted to rebut this claim by pointing out that other "officers of the court" were so entitled. Id., Sept. 4, 1810.

113. Kilty's report was a revival of the earlier attempt to determine the reception of British statutes into Maryland law. See p. 15 supra.

114. During the two terms in 1810 for Baltimore and Harford Counties, court was in session for 106 days. The chief justice, Joseph $H$. Nicholson, sat 101 days on the bench, but Jones sat only 25 and Hollingsworth a mere 11. 1810 Votes and Proceedings, House 51.

115. 1810 Votes and Proceedings, House, 63, 91. Both men claimed they had been ill. Hollingsworth was at least eighty years old, and was said to have faithfully served the Revolution. He survived easily with only six votes against him in the House (including, however, leading lawyers, Bland and Archer).

116. Id. at 25-26. Bland had headed the House committee to consider Kilty's report. Perhaps Republican lawyers, now in control of the Maryland bench, meant to undermine confidence in the idea that the legislature should adopt an official list of received statutes.

117. For Maryland's bench and bar, Kilty's Report on the British Stat. ules in Force in Maryland (1812) became the foundational study of the reception of older British statutes into colonial Maryland law.

118. Maryland Republican (Annapolis), Dec. 18, 1810.

119. Id.

120. Id.

121. Id.

122. On Austin, see Bloomfield, American Lawyers, supra note 2, at 45; Cook, Codification, supra note 23, at 13-16, 20-25. An excerpt from Austin's writings is available in Honestus [Benjamin Austin, Jr.], Observations on the Pernicious Practice of the Law, as Published Occasionally in the Independent Chronicle, in the Year 1786 [1819], in Law and Jurisprudence in American History, ed. Stephen B. Presser and Jamil S. Zainaldin (1989), 252. 
123. Cf. Alan Watson, The Evolution of Law (1985). "Law . . . is above all and primarily the culture of the lawyers and especially of the lawmakers-that is, of those lawyers who, whether as legislators, jurists, or judges, have control of the accepted mechanisms of legal change." Id. at 118. 